\title{
REFLEKSI KRITIS KONDISI DEMOGRAFI INDONESIA: ANTARA BONUS DAN BENCANA DEMOGRAFI
}

\section{Made Sarmita}

Masuk: 01022017 / Diterima: 01042017 / Dipublikasi: 30062017 (c) 2017Fakultas Hukum dan IImu Sosial UNDIKSHA dan IG

\begin{abstract}
In quantity, Indonesia can be said will soon enjoy the demographic dividend because the large number of population is a productive age. But the large number of productive age population was not followed by a reliable quality and this can actually be a demographic disaster. This article presents the outlook as a critical reflection of Indonesia's current demographic condition derived from the review of demographic data and related writings. The results obtained are that the demographic conditions of Indonesia are in the "crossroads". In terms of quantity, Indonesia will enjoy demographic dividend, but in terms of the quality of Indonesia will be faced with the demographic disaster. Real, immediate and continuous efforts that can be done include improving the quality of human resources, especially through education and health, creating jobs by all parties, placing the elderly population as an asset, and consolidating the agricultural sector through the empowerment of local farmers as well as cutting wages between agriculture and non-agricultural sectors.
\end{abstract}

Key words: Demographic, Dividend, Disaster

\begin{abstract}
Abstrak Secara kuantitas, Indonesia dapat dikatakan akan segera menikmati bonus demografi karena besarnya jumlah penduduk usia produktif. Namun besarnya jumlah penduduk usia produktif ternyata belum diikuti dengan kualitas yang handal dan hal ini justru bisa menjadi bencana demografi. Artikel ini menyajikan pandangan sebagai sebuah refleksi kritis tentang kondisi demografi Indonesia saat ini yang diperoleh dari hasil review data demografi dan tulisan-tulisan terkait. Adapun hasil yang diperoleh adalah bahwa kondisi demografi Indonesia memang sedang berada di "persimpangan jalan". Dari sisi kuantitas, Indonesia akan menikmati bonus demografi, tetapi dari sisi kualitas Indonesia akan dihadapkan pada bencana demografi. Upaya-upaya riil, segera, dan bersifat continue yang bisa dilakukan diantaranya meningkatkan kualitas sumber daya manusia terutama melalui pendidikan dan kesehatan, menciptakan lapangan pekerjaan oleh seluruh pihak, menempatkan penduduk usia lanjut sebagai aset, dan pemantapan sektor pertanian melalui pemberdayaan petani lokal sekaligus memangkas upah antara sektor pertanian dengan non-pertanian.
\end{abstract}

Kata-kata kunci : Demografi, Bonus, Bencana

\section{Pendahuluan}

Secara garis besarnya, penduduk mempunyai tiga matra pokok, yaitu aspek kuantitas, kualitas, serta persebaran penduduk.Disamping ketiga matra ini, ada aspek pendukung lainnya yaitu masalah administrasi

\section{Made Sarmita}

Jurusan Pendidikan Geografi, FHIS UNDIKSHA Singaraja made.sarmita@undiksha.ac.id kependudukan yang berkenaan dengan ketiga matra tersebut. Di Indonesia, keempat aspek kependudukan ini masih menghadapi kendala dan tantangan yang cukup berat.

Pertama, aspek kuantitas terutama dilihat dari jumlah penduduk dan tren perkembangannya.Jumlah penduduk Indonesia masih berada di tangga atas, bersama-sama dengan Negara China, India, dan Amerika. 
Sensus yang terakhir menyajikan data jumlah penduduk Indonesia mencapai 237,6 juta jiwa dan tahun 2015 sudah melampaui angka 250 juta jiwa. Ratarata laju pertumbuhan penduduk mengalami peningkatan dari periode sebelumnya, dari $1,37 \%$ di periode 1990-2000 meningkat menjadi 1,49\% di periode 2000-2010. Angka LPP tersebut jauh melampaui target yang ditetapkan sebesar 1,1\%. Target angka TFR di akhir era MDGs sebesar 2,1 anak per perempuan usia reproduksi sepertinya sulit tercapai (Bappenas, 2011). Angka fertilitas total di tiga survei demografi dan kesehatan Indonesia menunjukkan stagnanisasi di angka 2,6.Banyak lagi indikatorindikator demografi lainnya yang ternyata tidak berjalan sesuai harapan sehingga sasaran pengendalian kuantitas penduduk di akhir millennium tidak tercapai sehingga perlu perhatian khusus.

Reformasi telah membuat persoalan demografi bukan soal strategis lagi.Hal itu ditunjukkan dari realita seperti berikut ini.

- Otonomi daerah telah menjadikan pemerintah pusat tidak lagi memiliki gigi di daerah untuk urusan Keluarga Berencana (KB)

- Pilkada langsung telah menjadikan kepala daerah yang sudah otonom itu fokus pada "keterpilihan". Mereka memilih program-program yang instan dan sebaliknya malas pada program strategis berjangka panjang. Mereka memilih pembangunan infrastruktur, bantuan sosial dan seterusnya yang langsung dirasakan masyarakat.
- Struktur organisasi pemerintah daerah dan penganggaran tidak lagi berpihak pada masalah demografi. Di pusat pun BKKBN tidak begitu diperhatikan.

Apa yang terjadi kemudian? Jumlah penyuluh lapangan program KB berkurang drastis.Saat ini hanya ada 15000 orang, dipuncak prestasinya pada masa orde baru ada 50000 penyuluh lapangan. Mereka pensiun atau dialihkan ke dinas lain. Pengabaian terhadap program KB membuat petugas di lapangan tidak lagi memiliki kebanggaan dan prospek karier tidak lagi menjanjikan. Mencermati geliat demografi ini ibarat mendeteksi getaran gunung berapi.Ketika bisa siaga dan menghindarkan diri dari bencana letusan gunung jika bisa cermat terhadap perubahan getaran di perut bumi. Munculnya "Arab Spring" di Timur Tengah salah satunya bisa dilihat dari sisi demografi ini. Sekitar 25\% penduduk usia muda terdidik (19-24 tahun) adalah pengangguran. Angka $25 \%$ adalah garis merah bagi lahirnya revolusi dan chaos. Saat ini penduduk usia terdidik Indonesia yang menganggur sekitar $18 \%$, sudah masuk lampu kuning dan angkanya cenderung naik. Banyaknya penduduk usia produktif yang belum diimbangi dengan berkembangnya lapangan pekerjaan yang sesuai akan membuat banyak pengangguran intelektual berkeliaran.

Dari sisi kualitas, penduduk Indonesia dapat dikatakan masih tergolong rendah.Jumlah penduduk Indonesia yang besar ternyata belum diimbangi dengan mutu sumber daya manusia yang memadai.Indeks 
Pembangunan Manusia/ Human Development Index Indonesia dalam tiga tahun terakhir masih berada ditataran bawah (urutan ke-110 dari 188 negara-negara di dunia) (UN, 2015).Kualitas penduduk yang masih rendah terutama ditandai dengan ratarata tingkat pendidikan penduduk yang masih rendah serta angka kematian yang masih tergolong tinggi (dibandingkan negara-negara lainnya, walaupun sudah terjadi penurunan).Fenomena ketiga adalah masalah persebaran atau distribusi penduduk.Masih dijumpai ketimpangan persebaran penduduk yang tidak merata dan terkonsentrasi hanya di pulau Jawa, Madura, Bali, dan Lombok (JAMBAL).Menurut hasil sensus penduduk 2010, sebagian besar penduduk Indonesia (60\%) masih bertempat tinggal di empat pulau tersebut (JAMBAL) yang luasnya hanya sekitar 7 sampai $8 \%$ dari seluruh luas daratan Indonesia, sedangkan $40 \%$ penduduk sisanya bertempat tinggal di luar pulau-pulau JAMBAL yang luasnya jauh lebih besar. Kondisi demikian tentu berimplikasi terhadap kemampuan daya tampung dan daya dukung lingkungan yang pada gilirannya dapat menurunkan derajat hidup dan permasalahan lingkungan hidup bagi penduduk. Jumlah penduduk yang tidak merata dan berjejal di suatu wilayah akan memberikan beban yang berat bagi wilayah yang bersangkutan (BKKBN, 2014)

Penduduk sebagai modal dasar pembangunan adalah titik sentral dalam mewujudkan pembangunan berkelanjutan. Jumlah penduduk yang besar dengan laju pertumbuhan penduduk yang cepat, kualitas yang rendah serta diiringi persebaran yang tidak merata akan memperlambat tercapainya tujuan pembangunan. Tidak mengherankan, permasalahan klasik dan terus mengakar yang dihadapi bangsa kita selalu terkait dengan kemiskinan dan pengangguran sebagai outcome dari bekerjanya tiga matra kependudukan tersebut.

Dari permasalahanpermasalahan yang ada, ternyata terselip sebuah kesempatan yang jika dimanfaatkan dengan maksimal akan sangat berguna bagi kemajuan dan kebesaran bangsa. Beranjak dari hal tersebut, maka dalam artikel ini akan dijawab pertanyaan-pertanyaan berikut.

1. Apakah pertumbuhan penduduk Indonesia sebagai momentum menuju kesejahteraan atau kesengsaraan?

2. Bagaimana upaya yang dapat dilakukan dalam memanfaatkan kondisi demografis Indonesia?

\section{Metode}

Penulisan artikel ini dilakukan dengan metode rasionalistik dengan pendekatan deskriptif kualitatif, mengacu pada empiri yang bersifat realitas sebagai sumber kebenaran.Metode rasionalistik pada umumnya bertujuan untuk menemukan sesuatu, bukan dimaksudkan untuk menguji suatu teori, sehingga tidak diharuskan menggunakan hipotesa (Djunaedi, 1989). Dengan metode ini, pembahasan dititikberatkan pada fenomena demografis Indonesia saat ini serta peluangnya di masa yang akan datang. Selain itu secara rasional juga diungkap beberapa hal yang sedianya bisa dilakukan dalam rangka 
memanfaatkan momentum demografis yang ada.

\section{Hasil dan Pembahasan}

\section{Pertumbuhan Penduduk Indonesia: Momentum Menuju Kesejahteraan atau Kesengsaraan?}

Apa yang sudah terjadi terkait dengan fenomena demografi yang berlangsung akhir-akhir ini tidak boleh hanya dilihat dari sisi negatif yang justru akan melahirkan rasa pesimis dalam upaya pembangunan di segala bidang. Fenomena demografi yang telah terjadi pada suatu saat perlu juga dilihat dari sisi positifnya. Karena dengan demikian, suatu refleksi kritis dan evaluasi positif yang sifatnya membangun untuk kepentingan masa depan bersamaakan terwujud.

Walaupun pertumbuhan penduduk Indonesia menunjukkan tren peningkatan dalam satu periode terakhir, namun tetap disyukuri bahwasannya peningkatan ini terjadi tidak hanya dipengaruhi oleh stagnannya tingkat fertilitas, akan tetapi dipengaruhi pula oleh semakin menurunnya tingkat mortalitas penduduk dimana angka harapan hidup penduduk Indonesia yang terus semakin meningkat $(68,9$ tahun di akhir tahun 2014). Majunya teknologi dalam bidang kesehatan menolong pemerintah yang ikut serta dalam penurunan mortalitas penduduk.

Di sisi lainnya, pertumbuhan penduduk berdasar pada komposisi umur menunjukkan tren yang cukup baik dan "sepertinya" bisa dijadikan momentum menuju kesejahteraan. Bertambahnya penduduk Indonesia dilihat dari komposisi umur juga dikontribusikan oleh bertambahnya penduduk usia produktif. Bappenas menyatakan keadaan ini di satu sisi mengindikasikan telah terjadi penurunan persentase penduduk sebagai beban pembangunan, sementara di sisi lain juga merupakan suatu "jendela kesempatan" (window of opportunity) karena penduduk tidak lagi menjadi beban, namun sebaliknya menguntungkan pembangunan. Keadaan penduduk Indonesia saat ini dilihat dari aspek kuantitas dapat dilihat pada gambar berikut.

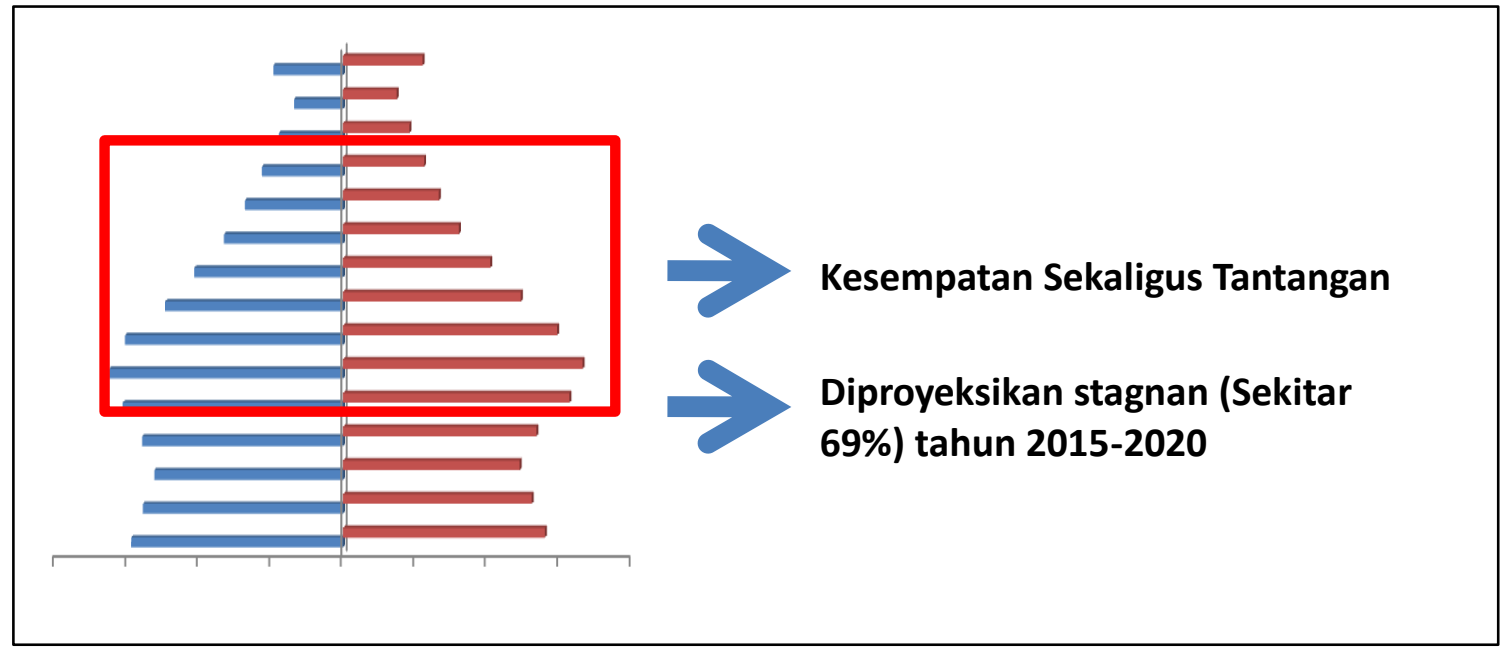

Gambar 1. Piramida Penduduk Indonesia Tahun 2010 (BPS, SP 2010) 
Window of opportunity terkenal dengan nama "Bonus Demografi" (Demographic Dividend) dimana akan membawa dampak sosial ekonomi, jumlah penduduk yang produktif akan menanggung penduduk yang belum dan tidak produktif. Harapannya adalah jumlah penduduk usia produktif menjadi modal pembangunan, yaitu sebagai sumberdaya manusia yang potensial sehingga perekonomian negara dapat meningkat dan kesejahteraan masyarakat akan tercapai. Permasalahannya adalah mampukah negara kita saat ini menghadapi momentum bonus demografi?Saat ini pengangguran masih tidak terelakkan sehingga fenomena kemiskinan masih menjadi sesuatu yang lumrah.

Potensi penduduk dengan tersedianya tenaga-tenaga produktif yang berlimpah jangan sampai menjadi "Bencana Demografi" (Demographic Disaster), yakni tidak bermanfaatnya sumberdaya manusia produktif yang menjadi sia-sia karena tidak adanya alokasi dan sarana prasarana lapangan pekerjaan yang cukup untuk mengoptimalkan peran penduduk usia produktif. Oleh karena itu, dibutuhkan kecermatan dari pemerintah, masyarakat, serta seluruh stakeholdersagar negara kita benarbenar siap menghadapi bonus demografi ini.

Bonus demografi sesungguhnya suatu kesempatan yang sangat langka dan bisa jadi hanya terjadi satu kali saja.Hal ini terjadi bila suatu masyarakat atau bangsa berhasil mengubah struktur umur penduduknya dari bentuk piramid (Indonesia sebelum merdeka - Tahun 1990an) menjadi bentuk kubah (kondisi saat ini dan diprediksi hingga 2040an), dan kemudian menuju ke bentuk granat. Dalam perjalanan perubahan itu, akan bisa dihitung berapa banyak penduduk yang berusia produktif (15 - 64 tahun) dibanding yang berada di usia belum produktif (0 - 14 tahun) dan usia tidak produktif lagi $(65+)$. Bila suatu bangsa struktur umur penduduknya piramid atau granat maka, 100 penduduk usia produktif akan disertai dengan $70-80$ atau lebih penduduk usia belum dan tidak produktif. Hanya bedanya kalau pada bentuk piramid yang banyak adalah penduduk usia belum produktif, sementara bentuk granat yang banyak adalah lansia (65+). Suatu masyarakat dikatakan memasuki dan atau mengalami bonus demografi bila berada dalam struktur yang berbentuk kubah tadi, yakni 100 penduduk usia produktif hanya diimbangi oleh sekitar 40 - 50 penduduk usia belum dan tidak produktif. Artinya bahwa beban menjadi tidak terlalu berat bagi penduduk usia produktif. Bila keberhasilan program KB dapat dipertahankan dan berhasil mencapai Total Fertility Rate (TFR) sekitar 2,1 maka pada tahun 2020 2030 Indonesia akan mengalami bonus demografi dengan angka ketergantungan (dependency ratio) sekitar 40 sampai 50 .

Struktur umur penduduk
Indonesia saat ini sangat menguntungkan untuk pembangunan ekonomi. Jumlah penduduk usia kerja relatif jauh lebih besar daripada jumlah penduduk yang menjadi beban (anak dan lansia). Inilah kesempatan emas yang amat berharga. Disebut bonus, karena kesempatan ini tidakakan bertahan lama. Angka ketergantungan muda akan terus menurun, tetapi lama 
kelamaan penurunannya akan semakin pelan. Di sisi lain, peningkatan angka ketergantungan tua akan meningkat dan terus meningkat dengan cepat. Oleh sebab itu suatu titik akan tercapai ketika peningkatan angka ketergantungan tua lebih besar daripada penurunan angka ketergantungan muda. Di saat itu, angka ketergantungan total meningkat dan beban demografis pada perekonomian meningkat kembali (Krista, 2008).

Kaitannya dengan pertumbuhan ekonomi, momentum bonus demografi perlu benar-benar dimanfaatkan secara maksimal.Secara lebih spesifik, Bongaarts dan Blom (dalam Adioetomo, 2005) menyatakan bahwa ada empat faktor penting dalam menjelaskan bonus demografi yang berkaitan dengan pertumbuhan ekonomi yaitu penawaran tenaga kerja (labour supply), peranan perempuan, tabungan (savings), dan modal manusia (human capital).

\section{Penawaran tenaga kerja}

Ada dua hal yang mempengaruhi penawaran tenaga kerja. Secara umum adalah generasi baby boom yang diiringi dengan penurunan kematian bayi, semakin lama akan menjadi dewasa dan mencapai usia kerja. Jumlahnya meningkat dengan pesat. Penurunan fertilitas yang kemudian mengikuti penurunan jumlah kematian bayi akan menyebabkan proporsi penduduk usia kerja akan semakin besar dibandingkan dengan proporsi penduduk usia muda (bayi). Mereka ini akan bekerja dan pada usia paling aktif (untuk bekerja) yaitu antara usia 20 54 tahun. Hal ini tentu akan berdampak terhadap pertumbuhan ekonomi yang semakin baik dengan catatan mereka terserap kedalam pasar kerja. Tersedianya lapangan kerja yang menyalurkan penduduk usia produktif untuk bekerja senantiasa meningkatkan pendapatan per-kapita yang pada akhirnya akan memicu peningkatan pendapatan nasional.

\section{Peranan perempuan}

Bongaarts mengatakan bahwa penentu fertilitas adalah proporsi wanita kawin di usia belia (15-19 tahun), pemakaian kontrasepsi, aborsi, kemandulan, frekuensi hubungan seksual, selibat permanen, dan mortalitas janin. Kemudian menurut Kingsley Davis dan Judith Blake menyatakan penurunan fertilitas diakibatkan oleh adanya faktorfaktor yang mempengaruhi terjadinya konsepsi salah satunya adalah dengan pemakaian alat kontrasepsi (Rujiman, 2010). Dengan adanya program KB, wanita akan lebih sedikit untuk mengurus anak dan cenderung untuk bekerja. Emansipasi wanita tempo dulu yang sangat membatasi pergerakan kaum wanita, menjadi penghambat bagi wanita untuk memberikan kontribusi yang nyata bagi perekonomian. Bergerak dengan adanya globalisasi, emansipasi pada wanita sekarang dapat luput sehingga wanita memiliki peran yang sama dengan pria. Pergerakan wanita tidak dibatasi, namun justru pemberdayaan pada wanita digalakkan sehingga wanita lebih produktif dapat ikut meningkatkan pendapatan nasional.

\section{Tabungan}

Bonus demografi memicu pertumbuhan tabungan (savings) dan pada gilirannya 
akan meningkatkan investasi dan pertumbuhan ekonomi. Model-model ekonomi tentang tabungan yang berhubungan langsung dengan penduduk adalah age dependency model dengan landasan pemikiran bahwa terhindarnya kelahiran seorang bayi (a birth averted) akan menyebabkan menurunnya sejumlah konsumsi yang meningkatkan tabungan dan menyebabkan terjadinya pembentukan kapital (Ogawa, dalam adioetomo, 2005). Higgins (dalam Adioetomo, 2005) mengatakan ada accounting effectsdan behavioral effects. Penduduk muda dan penduduk lansia mengkonsumsi barang melebihi apa yang mereka bisa produksi, sedangkan penduduk yang usia kerja cenderung mempunyai tingkat output ekonomi yang lebih tinggi dan cenderung pula mempunyai tingkat tabungan yang lebih tinggi pula. Hal ini sesuai dengan hipotesis Coale dan Hooveryang menemukan bahwa penduduk mulai menabung lebih banyak pada usia 40 sampai 65 tahun pada saat mereka sudah tidak terbebani oleh pembiayaan anak-anak. Pada usia ini mereka juga mempersiapkan masa pensiun. Sejalan dengan bergesernya umur dan implikasinya terhadap jumlah usia produktif, akumulasi aset akibat adanya proses penuaan penduduk (population ageing) adalah keuntungan yang harus diperhitungkan selanjutnya (Maliki, 2010).Boongarts juga menyatakan bahwa tabungan menjadi salah satu indikator pertumbuhan ekonomi apabila diinvestasikan secara produktif dan ini menyangkut kebijakan pemerintah dalam menyediakan iklim kondusif untuk investasi.

\section{Modal Manusia}

Ketersediaan sumber daya manusia yang produktif bukan lagi menjadi objek pembangunan, tetapi sekaligus menjadi subjek pembangunan. Mereka yang senantiasa akan menjadi pelaksana pembangunan. Partisipasi modal manusia tidak hanya sekedar jumlah yang besar, akan tetapi yang terpenting adalah harus diimbangi dengan skill yang potensial. Pendidikan sebagai jalan utama untuk menciptakan produktivitas pada sumber daya modal sehingga dengan orang yang berkualitas akan melahirkan manfaat yang luar biasa pula.

Momentum pertumbuhan penduduk yang ada sekaligus buah kebijakan kependudukan di era sebelumnya telah membawa Indonesia memasuki era bonus demografi. Keadaan ini harus benar-benar dimanfaatkan bersama, bukan hanya tugas pemerintah tetapi seluruh komponen bangsa memiliki peranan dan tugas yang sama sehingga keadaan seperti ini bisa menjadi berkah untuk kemajun bangsa. Apabila momentum ini tidak dimanfaatkan, justru akan mebawa Indonesia ke masa kegelapan terlebih di era global dan persaingan tanpa batas seperti saat ini. Dari sisi kuantitas kondisi Indonesia sudah sangat mendukung.Saat ini yang memerlukan perhatian khusus adalah dari sisi kualitas sumber daya manusia yang terus menerus perlu ditingkatkan secara bersama-sama.

\section{Upaya Dalam Memanfaatkan Kondisi Demografi Indonesia}

Berkaca dari fakta yang ada, nilai Indeks Pembangunan Manusia/ Human Development Index Indonesia 
dalam tiga tahun terakhir masih berada ditataran bawah (urutan ke-110 dari 188 negara-negara di dunia dan urutan ke-5 dari 10 negara di Asean) dengan nilai 68,4 (UN, 2015). Permasalahan pembangunan sumber daya manusia inilah yang harusnya bisa diselesaikan dari sekarang untuk dapat memanfaatkan momentum bonus demografi.Jangan sampai hal yang menjadi berkah justru membawa bencana dan membebani negara karena permasalahan yang mendasar. Dalam hal ini, pemerintah harus mampu menjadi agent of development dengan cara memperbaiki mutu manusia Indonesia yang dimulai dari pendidikan, kesehatan, hingga penguasaan teknologi dan komunikasi dan pada akhirnya kesejahteraan masyarakat meningkat (aspek ekonomi). Secara lebih konkretnya, beberapa upaya yang bisa dilakukan dalam upaya memanfaatkan bonus demografi adalah sebagai berikut.

\section{Menciptakan sumber daya manusia yang berkualitas}

Menurunnya jumlah anak yang dilahirkan memberikan keleluasaan untuk meningkatkan kualitas keluarga.Segala pengeluaran bisa lebih difokuskan pada bidang pendidikan dan kesehatan untuk meningkatkan kualitas sumber daya manusia yang kompetitif. Peningkatan kualitas penduduk usia produktif dapat dilakukan dengan memberikan bekal keterampilan yang sesuai dengan kebutuhan pasaran kerja dengan kualitas yang kompetitif. Bonus demografi hanya akan terjadi ketika ada upaya rekayasa demografi yang dibarengi dengan peningkatan kualitas sumber daya manusia.

\section{Menciptakan lapangan pekerjaan}

Bonus demografi mempersyaratkan penduduk usia produktif untuk benarbenar produktif (dalam artian ekonomi). Agar penduduk menjadi produktif, maka hal utama yang harus ada adalah tersedianya lapangan pekerjaan.Di satu sisi, pemerintah dituntut terus menciptakan lapangan pekerjaan baru dan mempermudah investasi yang ramah terhadap lingkungan kerja Indonesia. Apabila dimungkinkan, investasi lebih ditekankan pada sistem padat karya atau setengah padat karya utamanya di daerah pedesaan (Sarmita, 2015). Pada sisi selanjutnya, penduduk juga diharapkan aktif untuk terus berinovasi sehingga tidak selalu tergantung dengan upaya pemerintah. Mindset penduduk perlu dirubah, dari pola lama: "melamar pekerjaan", menjadi "menciptakan lapangan pekerjaan".

Untuk itu, modal dasar yang diperlukan menuju kearah tersebut adalah perlunya revolusi dalam kurikulum pendidikan yang mana dalam setiap mata pelajaran/perkuliahan menyelipkan unsur-unsur kewirausahaan dalam diri peserta didik.Hal ini perlu dilakukan mulai dari pendidikan dasar hingga perguruan tinggi tanpa mengenyampingkan pendidikan karakter yang sudah berjalan saat ini. Saat ini hal demikian belum maksimal dilakukan terutama di tingkat perguruan tinggi. Akibatnya, jumlah pengangguran terdidik terus bertambah karena tidak semua lulusannya dapat tertampung di dunia kerja akibat minimnya keterampilan dan jiwa wirausaha yang dimiliki (Maryati, 2015). 


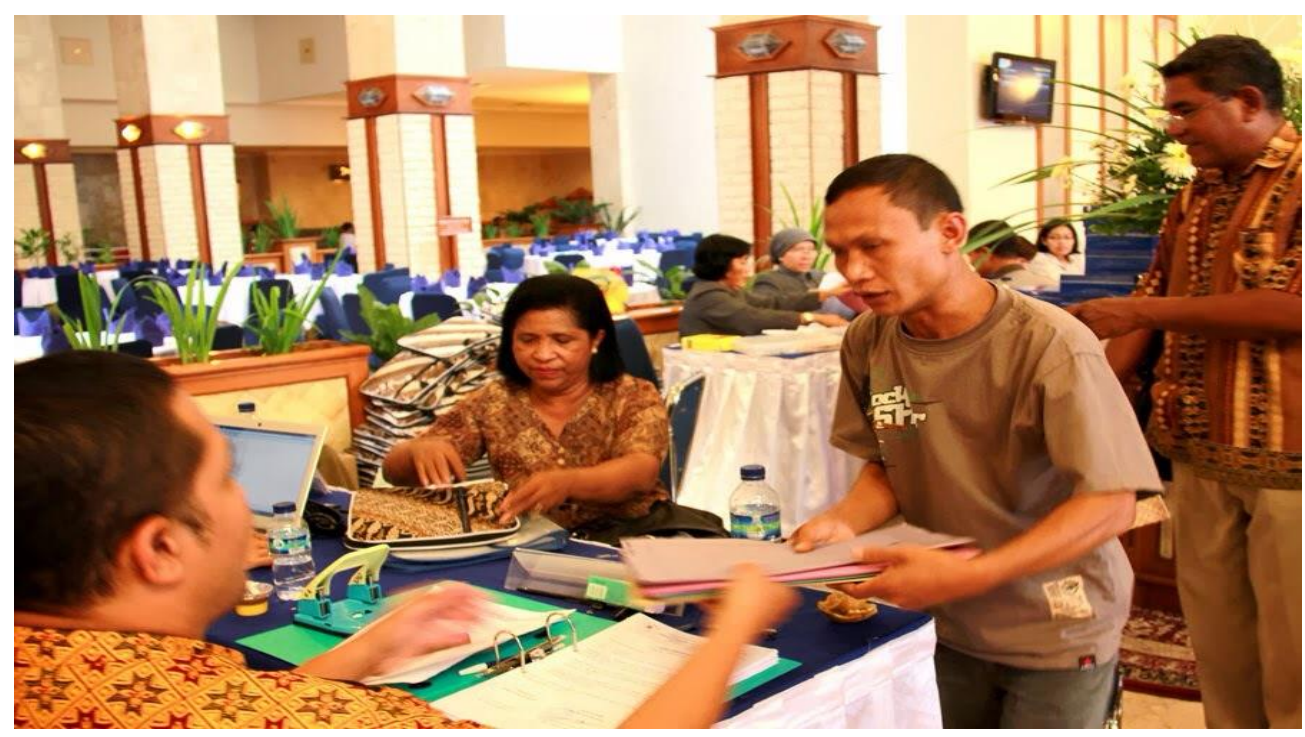

Gambar 2. Mindset Pola "Melamar" Pekerjaan perlu dirubah menjadi "Membuka" Lapangan Pekerjaan

\section{Menempatkan penduduk usia lanjut sebagai asset, bukan beban.}

Banyak penelitian menyebutkan bahwa penduduk usia lanjut di Indonesia masih terus dan tetap berproduksi. Pada usia 65 tahun ke atas, mereka masih menggunakan kemampuannya untuk memenuhi sekitar 40 persen kebutuhan konsumsinya, dimana penduduk usia lanjut miskin dan tidak miskin tidak banyak memiliki perbedaan. Penelitian serupa dilakukan Cameron (2000) dan McKee (2005) (dalam Maliki, 2010) yang menemukan hal serupa yaitu bahwa kelompok usia tua Indonesia terus bekerja terutama di sektor pertanian dan non pertanian. Meskipun alasan utama untuk terus bekerja adalah kurang siapnya perbekalan masa tua serta masih adanya anak/cucu yang harus dibantu, tingginya partisipasi kerja penduduk usia lanjut merupakan hal positif yang bisa terus dioptimalkan. Berada di era bonus demografi dan kelanjutannya di masa mendatang, peningkatan penduduk usia lanjut di masa yang akan datang dapat dijadikan sebagai potensi dibandingkan beban. Penduduk usialanjut dengan permasalahan kesehatan dan produktivitasnya yang terus menurun dapat menjadi beban. Namun dengan peningkatan kualitas kesehatan yang ada, penduduk usia lanjut diharapkan untuk terus bisa berproduksi.

\section{Pemantapan sektor pertanian melalui pemberdayaan petani lokal}

Pemantapan sektor pertanian sebagai basis untuk memberdayakan petani lokal agar lebih produktif dengan sistem padat karya.Agar mereka lebih produktif, perlu dari pihak pemerintah untuk terus memberikan semacam penyuluhan, inovasi, bantuan, dan jaminan kerja kepada para petani dengan mengadopsi keberhasilan sistem pertanian di negara-negara lainnya.Pemerintah juga harus berupaya dalam mempersempit 
kesenjangan upah antara pekerja di sektor pertanian dengan non-pertanian.

Sekiranya, keempat upaya di atas penting dan mendesak untuk dilakukan oleh seluruh stakeholdhers yang ada. Sistem "jemput bola" wajib diterapkan, tanpa menunggu datangnya pekerjaan, akan tetapi berani berkreasi dan terus menerus berinovasi. Memasuki dunia kerja, khususnya para akademisi tidak hanya terkungkung dalam batas bidang keilmuannya, akan tetapi ada kalanya berani untuk "sementara" melepas idealismenya dan mencoba suatu pekerjaan lain sekalipun pekerjaan itu mungkin jauh dari scientific background yang dimiliki. Rasa "gengsi" dan sejenisnya didalam memilih-milih pekerjaan perlu dibuang jauh-jauh. Jika hal itu tidak dilakukan, para akademisi hanya akan menambah rentetan pengangguran intelektual seperti yang terjadi saat ini.

\section{Penutup}

Mengacu pada kondisi demografi saat ini, Indonesia masih memiliki beragam permasalahan diantaranya jumlah penduduk yang besar, kualitas penduduk yang rendah, dan distribusi penduduk yang belum merata.Diantara permasalahan yang ada, terselip sebuah fenomena demografi yang unik, tercipta sebagai akibat penerapan kebijakan kependudukan di masa lalu. Fenomena itu adalah bonus atau justru bencana demografi. Akan menjadi bonus, apabila modal utama yakni kualitas penduduk terus meningkat dan ketersediaan lapangan pekerjaan yang memadai untuk menampung seluruh penduduk usia produktif.
Sampai saat ini upaya pemerintah sudah menuju ke arah itu dan masih berproses. Sebaliknya, akan menjadi bencana dengan melihat realita yang ada sekarang (kualitas penduduk usia produktif yang masih rendah; ketersediaan lapangan pekerjaan yang belum memadai; pengangguran intelektual) ditengahtengah memasuki fase awal dari jendela kesempatan (the window of opportunity). Walaupun masih berada di "persimpangan jalan",setidaknya upaya-upaya yang ditawarkan untuk bisa dilakukan bersama (tidak hanya tugas pemerintah) dalam memanfaatkan momentum ini adalah memberikan perhatian dan terutama action dibidang pendidikan, kesehatan, dan ketenagakerjaan.

\section{Daftar Pustaka}

Adioetomo, Sri Moertiningsih Setyo. 2005. Bonus Demografi Menjelaskan Hubungan Antara Pertumbuhan Penduduk Dengan Pertumbuhan Ekonomi (Pidato Pengukuhan Guru Besar Tetap Dalam Bidang Ekonomi Kependudukan di FEUI). Jakarta.

BAPPENAS.2011. Laporan Pencapaian

Tujuan

Pembangunan

Millenium Di Indonesia.

Jakarta: Kementerian

Perencanaan Pembangunan

Nasional

BPS. 2010. Hasil Sensus Penduduk 2010. Jakarta: Badan Pusat Statistik

BKKBN. 2014. Grand Design Pengendalian Kuantitas Penduduk Indonesia. Jakarta: 
Badan Kependudukan dan Keluarga Berencana Nasional

Djunaedi, Achmad. 1989. Pengantar Metodologi Penelitian Arsitektur. Fakultas Teknik : UGM

Krista, Maria. 2008. Menyongsong Bonus Demografi. Tersedia dalam

www.kristamariapujantoro.blog spot.com/2008, diakses pada tanggal 1 desember 2016

Maliki.2010. Pemanfaatan Bonus Demografi Sebagai Alternatif Sumber Pembiayaan Pembangunan. Majalah Triwulan: Perencanaan Pembangunan, EDISI 01/Tahun 2010. ISSN 08543709, Halaman 2-9

Maryati, Sri. 2015. Dinamika Pengangguran Terdidik; Tantangan Menuju Bonus Demografi Di Indonesia. Journal of Economic and Economic Education, Vol.3 No.2 ISSN 2302 - 1590 Halaman 124 - 136 